\title{
Endocannabinoid Brain System Involvement in Dopamine Mechanisms of Behavioural Sensitization to Psychostimulants
}

\author{
Dagmar Vršková \\ Department of Pharmacology, Faculty of Medicine, Masaryk University Brno, Czech Republic \\ Received May 19, 2008 \\ Accepted May 18, 2009
}

\begin{abstract}
The paper deals with the involvement of endocannabionid brain system in dopamine mechanisms of behavioural sensitization to psychostimulants. The development and manifestation of behavioural sensitization to methamphetamine are described. Results obtained in our previous studies, showing an interaction between the endocannabinoid system and methamphetamine brain mechanisms, in the rat intravenous drug self-administration model and with qPCR CB1 mRNA expression, are discussed.
\end{abstract}

Behavioural sensitization, endocannabinoid system, dopamine, methamphetamine, review

Psychostimulants elicit during repeated administration behavioural sensitization, a phenomenon characterised by a gradually increasing response to the drug. It has been described that the crucial importance for reward-related effects of abused drugs is associated with dopamine; furthermore, that structures involved in development of sensitization to psychostimulants are parts of the midbrain; and finally, that dopamine D1 and D2 receptors play critical roles in the development of altered behavioural response. In addition, there is accumulated evidence suggesting that various aspects of drug dependence are regulated also by endocannabinoid system. The endocannabinoid system consists of two cannabinoid receptors (CB1, CB2), endogenous cannabinoids, and the molecules involved in the inactivation of endocannabinoids. A reciprocal crosstalk is reported between the cannabinoid CB1 and dopamine receptors, which are highly co-localized on brain neurons. This supports other findings suggesting the involvement of endocannabinoid system in dopamine mechanisms underlying behavioural sensitization to psychostimulants. This article shortly reviews the roles of dopamine and endocannabinoid system in processes of behavioural sensitization.

Repeated administration of various drugs of abuse may result in an increase in behavioural response to these substances. This phenomenon is well known and described as behavioural sensitization (Robinson and Berridge 1993; Ohmori et al. 2000). Sometimes it is also called "reverse tolerance" in contrast to tolerance (a decreasing response after repeated drug administration). Behavioural sensitization is usually manifested after both repeated doses and application of a "challenge dose" administered after a certain period of withdrawal. Behavioural sensitization is believed to be caused by persistent adaptations in striatal neurotransmission associated with repeated exposure to drugs of abuse, and is thought to play an important role in certain aspects of drug addiction (Vanderschuren et al. 2001). For the development of behavioural sensitization in experimental models, intervals of drug administration are very important. Whereas tolerance occurs after continuous administration or after application of doses given in short intervals, development of sensitization is conditioned by administration of the substance in longer intervals, usually a minimum of 24 hours (Kalivas and Stewart 1991). Although behavioural sensitization in rodents has long been considered a model for the development of psychosis, recent reviews have underlined its potential importance as a model for the intensification of drug

Address for correspondence:

MVDr. Dagmar Vršková, Ph.D.

Department of Pharmacology

Faculty of Medicine, Masaryk University

Komenského náměstí 2

66243 Brno, Czech Republic

Phone: +420 549495081
Fax: +420 549492364
E-mail: dvrskova@med.muni.cz
http://www.vfu.cz/acta-vet/actavet.htm 
craving that characterizes addiction and promotes relapse (Robins on and Berridge 1993; Di Chiara 1995; Emmett-Oglesby 1995).

Under experimental circumstances the sensitization can be elicited to behavioural effects of majority of drugs of abuse in laboratory rodents. Thus behavioural sensitization has been described for instance in relation to amphetamine (Costa et al. 2001), cocaine (Elliot 2002), MDMA (Kalivas et al. 1998), opioids (De Vries et al. 1999), cannabinoids (Cadoni et al. 2001) or nicotine (Shoaib et al. 1994).

It is also well-known that an increased response to tested drug may be elicited by previous repeated administration of a drug different from the "challenge dose" of the drug tested. This phenomenon is termed cross-sensitization and it has been observed for example with tetrahydrocannabinol to morphine (Cadoni et al. 2001), heroin (Lamarque et al. 2001) or with morphine to methamphetamine (Landa et al. 2004). Thus not only behavioural sensitization (as mentioned above) but also cross-sensitization is considered to reinstate drug-seeking behaviour (De Vries et al. 2002).

\section{Manifestation of behavioural sensitization}

The most frequent features of sensitization observed are stimulatory effects of drugs. In laboratory rodents an increase in locomotor/exploratory activities is considered as the most common symptom of behavioural sensitization. Besides this, sensitization can occur to some other types of behaviour, such as stereotypic sniffing, head movements or rearing (Laviola et al. 1999), nose rubbing (Landa et al. 2005; Landa et al. 2008) and defensive-escape activities (Votava et al. 2002). However, there also are reports on sensitization to inhibitory drug actions such as catalepsy (Lanis and Schmidt 2001) or an anti-aggressive effect during social conflict in mice after repeated administration of methamphetamine (Landa et al. 2006b).

Although most research has focused on the characterization of sensitization to the behavioural effects of psychomotor stimulants in laboratory rodents, recent studies carried out on healthy human subjects, as well as drug users, suggest that behavioural sensitization also occurs in human beings (Strakowski et al. 1996; Bartlett et al. 1997). Strakowski et al. (1996) for example described behavioural sensitization after repeated administration of amphetamine in human volunteers that was manifested by increased activity and energy, elevated mood and speech rate (rate and amount).

There is increasing evidence indicating that behavioural sensitization can be parcelled into two temporally defined domains, called development (or initiation) and expression (Kalivas et al. 1993). The term "development" of behavioural sensitization refers to the progressive molecular and cellular alterations that culminate in a change in the processing of environmental and pharmacological stimuli by the CNS. These alterations are transient and may not be detected after a few weeks of withdrawal (Kalivas et al. 1993). The term "expression" of behavioural sensitization is defined as enduring neural changes that arise from the process of development an that directly mediate the sensitized behavioural response (Pierce and Kalivas 1997). Various data indicate that these processes are distinct not only temporally but also anatomically. Development of behavioural sensitization to psychostimulant drugs occurs in the ventral tegmental area and substantia nigra, which are the loci of dopamine cells in the ventral midbrain that give rise to the mesocorticolimbic and nigrostriatal pathways. In contrast, the neuronal events associated with the expression are distributed among several interconnected limbic nuclei that are centred on the nucleus accumbens (Pierce and Kalivas 1997).

\section{Neuronal basis of behavioural sensitization and cross-sensitization to drugs - relevant anatomical structures and neurotransmitters}

As can be seen from previous text, many studies indicate that behavioural sensitization has a neural basis and that the neuronal circuit important for behavioural sensitization consists 
of various structures in the central nervous system. It involves particularly dopaminergic, glutamatergic and GABAergic projections between ventral tegmental area, nucleus accumbens, prefrontal cortex, hippocampus and amygdala. The mesolimbic dopaminergic projection from the ventral tegmental area to the nucleus accumbens seems to be of crucial importance for reward-related effects of drugs of abuse (Kalivas et al. 1993). It has been proved that brain dopamine D1 receptor concentrations were selectively increased in the nucleus accumbens of methamphetamine users (Worsley et al. 2000). Furthermore, the mesolimbic and nigrostriatal dopamine systems also participate at the reinforcing and locomotor-stimulating effects of psychostimulant drugs (Wise and Bozarth 1987). Several reports suggest that the mesoaccumbens and nigrostriatal dopamine systems play a crucial role in both the development and expression of drug-induced behavioural sensitization. The locus of the development of behavioural sensitization is situated at the level of the midbrain dopamine cell bodies because for instance repeated treatment with amphetamine given into the ventral tegmental area or substantia nigra, but not the nucleus accumbens, neostriatum or prefrontal cortex, sensitizes rats to a subsequent peripheral challenge injection of amphetamine or cocaine (Vezina and Stewart 1990; Cador et al. 1995). Whereas these and other data suggest that the ventral tegmental area/substantia nigra is an important locus for the development of sensitization (Kalivas and Stewart 1991), it has been suggested, based on neurochemical and electrophysiological changes in dopamine transmission that for the expression of behavioural sensitization to psychostimulants nucleus accumbens plays the crucial role.

Gorriti et al. (1999) reported that when the animals were allowed 24 hours of withdrawal after the last (-) $-\Delta 9$ - tetrahydrocannabinol dose administered in a 14 day lasting design of treatment, behavioural sensitization to the acute effect of amphetamine could be observed similarly as in previous study of Moss et al. (1984). This was in contrast to effects of acute exposure to (-)- $\Delta$ 9-tetrahydrocannabinol which attenuated the psychomotor stimulation elicited by amphetamine, and chronic cannabinoid administration led to development of tolerance to these effects. These data support the existence of interactions between monoaminergic neurons (particularly dopamine) and the endogenous cannabinoid system which is nowadays under the intense scientific investigation of both endogenous cannabinoids and their specific receptors.

\section{The endocannabinoid system}

Tissues of mammals contain at least two types of cannabinoid receptors. The first one, CB1 cannabinoid receptor was cloned in 1990 (Matsuda et al. 1990) and the second one, CB2 cannabinoid receptor, was cloned in 1993 (Munro et al. 1993). CB1 receptors are present in the central nervous system and also in some peripheral tissues such as pituitary gland, immune cells, reproductive tissues, gastrointestinal tissues, sympathetic ganglia, heart, lung, urinary bladder and adrenal gland (Pertwee 1997). In contrast, CB2 receptors are found in highest density in immune cells, particularly B-cells and natural killer cells (Pertwee 1997).

For both $\mathrm{CB} 1$ receptor and $\mathrm{CB} 2$ receptor endogenous agonistic ligands have already been also described and they are as follows: arachidonoyl ethanolamide (anandamide) (Devane et al. 1992), 2-arachidonoyl glycerol (Mechoulam et al. 1998) and 2arachidonyl glyceryl ether (noladin ether) (Hanus et al. 2001). Anandamide acts as a partial cannabinoid receptor agonist with marginally higher $\mathrm{CB} 1$ than $\mathrm{CB} 2$ affinity but much less CB2 than CB1 efficacy (Pertwee 1999, 2000).

As mentioned above, the crucial importance for reward-related effects of drugs of abuse is associated with dopamine. This well known neurotransmitter acts through specific dopamine receptors. The dopaminergic receptors are divided into D1 and D2 groups. The D1 group consist of D1 and D5 receptors, which are positively linked to adenylate 
cyclase. The D2 group consists of D2, D3 and D4 receptors (von Bohlen und Halbach and Dermietzel 2002). D1 receptors are expressed among other in the mammalian forebrain, in the striatum, the amygdala, the mesencephalon, the hypothalamus and the hindbrain. Similarly, D2 receptors are widely distributed within the brain, too (striatum, mesencephalon, hypothalamus and hippocampus).

Following the results obtained in one of our previous studies, showing an interaction between the endocannabinoid system and methamphetamine brain mechanisms in the rat intravenous drug self-administration model (Vinklerová et al. 2002), we further investigated whether repeated pre-treatment with cannabinoid receptor ligands in mice would affect their response to methamphetamine challenge dose in the open-field test (Landa et al. 2006a). We elicited cross-sensitization to methamphetamine after pre-treatment with $\mathrm{CB} 1$ receptor agonist methanandamide (a synthetic analogue of endocannabinoid anandamide) and on the contrary, we were able to block sensitization to methamphetamine by repeated pre-treatment with cannabinoid CB1 receptor antagonist AM 251. These results clearly suggested that the activity of the endocannabinoid system is involved in the neuronal circuitry underlying the development of sensitization to methamphetamine. There are preliminary studies (Landa and Jurajda 2007ab) with limited number of animals where using qPCR an increase in CB1 mRNA expression after both methamphetamine and methanandamide first doses followed by decrease in CB1 mRNA expression observed after the challenge dose of methamphetamine in sensitized animals were demonstrated. Since the interaction between the endocannabinoid system and methamphetamine brain mechanisms and the reciprocal crosstalk reported between the cannabinoid CB1 and dopamine receptors, it would be worthwhile to further investigate the relative expression of $\mathrm{CB} 1, \mathrm{D} 1$ and $\mathrm{D} 2$ receptors in a structure involved in the sensitization processes (i.e. mesencephalon) during both the development and expression of this process.

\section{Zapojení endokanabinoidního systému v dopaminových mechanismech rozvoje behaviorální senzitizace $k$ psychostimulanciím}

Článek si klade za cíl poukázat na recentní údaje o funkci endokanabinoidního systému v rozvoji behaviorální senzitizace $\mathrm{k}$ látkám s psychostimulačním účinkem. Jsou popsány mechanismy vzniku, zapojení jednotlivých mozkových struktur a dopaminergních mechanismů nezbytných pro rozvoj behaviorální senzitizace k metamfetaminu. Dále jsou zmiňovány výsledky předchozích experimentálních studií (intravenózní self-administrace metamfetaminu na potkaním modelu a stanovení exprese CB1 receptorů u myší), které potvrzují interakce mezi endokanabinoidním systémem a rozvojem behaviorální senzitizace $\mathrm{k}$ metamfetaminu.

\section{References}

Barlett E, Hallin A, Chapman B, Angrist B 1997: Selective sensitization to the psychosis-inducing effects of cocaine: a possible marker for addiction relapse vulnerability? Neuropsychopharmacol 16: 77-82

Cadoni C, Pisanu A, Solinas M, Acquas E, Di Chiara G 2001: Behavioural sensitization after repeated exposure to 9-tetrahydrocannabinol and cross-sensitization with morphine. Psychopharmacology 158: 259-266

Cador M, Bjijou Y, Stinus L 1995: Evidence of a complete independence of the neurobiological substrates for the induction and expression of behavioural sensitization to amphetamine. Neuroscience 65: 385-395

Costa FG, Frussa-Filho R, Felicio FL 2001: The neurotensin receptor antagonist, SR48692, attenuates the expression of amphetamine-induced behavioural sensitisation in mice. Eur J Pharmacol 428: 97-103

De Vries TJ, Schoffelmeer AN, Binnekade R, Vanderschuren LJ 1999: Dopaminergic mechanisms mediating the incentive to seek cocaine and heroin following long-term withdrawal of IV drug self-administration. Psychopharmacology 143: 254-260

De Vries TJ, Schoffelmeer AN, Binnekade R, Vanderschuren LJ 2002: Relapse to cocaine- and heroin-seeking behavior mediated by dopamine D2 receptors is time-dependent and associated with behavioral sensitization. Neuropsychopharmacol 26: 18-26

Devane WA, Hanus L, Breuer A 1992: Isolation and structure of a brain constituent that binds to the cannabimoid receptor. Science 258: 1946-1949 
Di Chiara G 1995: The role of dopamine in drug abuse viewed from the perspective of its role in motivation. Drug Alcohol Dependence 38: 95-137

Elliot EE 2002: Cocaine sensitization in the mouse using a cumulative dosing regime. Behav Pharmacol 13: 407-415

Emmett-Oglesby MW 1995: Sensitization and tolerance to the motivational and subjective effects of psychostimulants. In: Hammer RT (ed.) The Neurobiology of Cocaine: Cellular and Molecular Mechanisms, CRC Press, Boca Raton, pp. 31-47

Gorriti MA, Rodriguez DE, Fonseca F, Navarro M, Palomo T 1999: Chronic (-)-delta9-tetrahydrocannabinol treatment induces sensitization to the psychomotor effects of amphetamine on rats. Eur J Pharmacol 365: 133-142

Hanus L, Abu-Lafi S, Fride E 2001: 2-arachidonyl glyceryl ether, an endogenous agonist of the cannabinoid CB1 receptor. Proc Natl Acad Sci USA 98: 3662-3665

Kalivas PW, Stewart J 1991: Dopamine transmission in the initiation and expression of drug- and stress-induced sensitization of motor activity. Brain Res Rev 16: 223-244

Kalivas PW, Sorg BA, Holka MS 1993: The pharmacology and neural circuitry of sensitization to psychostimulants. Behav Pharmacol 4: 315-334

Kalivas PW, Duffy P, White SR 1998: MDMA elicits behavioral and neurochemical sensitization in rats. Neuropsychopharmacol 18: 469-479

Lamarque S, Taghzouti K, Simon H 2001: Chronic treatment with Delta(9) - tetrahydrocannabinol enhances the locomotor response to amphetamine and heroin. Implications for vulnerability to drug addiction. Neuropharmacology 41: 118-129

Landa L, Jurajda M 2007a: Behavioural sensitization to methamphetamine affects expression of cannabinoid CB1 receptors in mouse midbrain. Behavi Pharmacol 18, Suppl. 1: S27-S28

Landa L, Jurajda M 2007b: Acute and repeated exposure to methamphetamine changes expression of CB1 receptor in mesencephalon of the mouse brain. Eur Neuropsychopharmacol 17, Suppl. 4: S557

Landa L, Slais K, Sulcova A 2004: Cross-sensitization with morphine to methamphetamine effects on locomotion in mice. Homeostasis 43: 43-44

Landa L, Slais K, Hanesova M, Sulcova A 2005: Interspecies comparison of sensitization to methamphetamine effects on locomotion in mice and rats. Homeostasis 43: 146-147

Landa L, Slais K, Sulcova A 2006a: Involvement of cannabinoid CB1 and CB2 receptor activity in the development of behavioural sensitization to methamphetamine effects in mice. Neuroendocrinol Lett 27: 63-69

Landa L, Slais K, Sulcova A 2006b: Impact of cannabinoid receptor ligands on behavioural sensitization to antiaggressive methamphetamine effects in the model of mouse agonistic behaviour. Neuroendocrinol Lett 27: $703-710$

Landa L, Slais K, Sulcova A 2008: Impact of cannabinoid receptor ligands on sensitization to metamphetamine effects on rat locomotor behaviour. Acta Vet Brno 77: 183-191

Lanis A, Schmidt WJ 2001: NMDA receptor antagonists do not block the development of sensitization of catalepsy, but make its expression state-dependent. Behav Pharmacol 12: 143-149

Laviola G, Adriani W, Terranova ML, Gerra G 1999: Psychobiological risk factors for vulnerability to psychostimulants in human adolescents and animal models. Neurosci Biobehav Rev 23: 993-1010

Matsuda LA, Lolait SJ, Brownstein MJ, Young AC, Bonner TI 1990: Structure of a cannabinoid receptor and functional expression of the cloned cDNA. Nature 346: 561-564

Mechoulam R, Fride E, Di Marzo V 1998: Endocannabinoids. Eur J Pharmacol 359: 1-18

Moss DE, Koob GF, McMaster SB, Janowsky DS 1984: Comparative effects of tetrahydrocannabinol on psychostimulant-induced behaviors. Pharmacol Biochem Behav 21: 641-644

Munro S, Thomas KL, Abu-Shaar M 1993: Molecular characterization of a peripheral receptor for cannabinoids. Nature 365: 61-65

Ohmori T, Abekawa T, Ito K, Koyama T 2000: Context determines the type of sensitized behaviour: a brief review and a hypothesis on the role of environment in behavioural sensitization. Behav Pharmacol 11: 211-221

Pertwee RG 1997: Pharmacology of cannabinoid CB1 and CB2 receptors. Pharmacol Ther 74: 129-180

Pertwee RG 1999: Pharmacology of cannabinoid receptor ligands. Curr Med Chem 6: 635-664

Pertwee RG 2000: Cannabinoid receptor ligands: clinical and neuropharmacological considerations, relevant to future drug discovery and development. Expert Opin Inv Drug 9: 1553-1571

Pierce RC, Kalivas PW 1997: A circuitry model of the expression of behavioral sensitization to amphetamine-like psychostimulants. Brain Res Rev 25: 192-216

Robinson TE, Berridge KC 1993: The neural basis of drug craving: an incentive-sensitization theory of addiction. Brain Res Rev 18: 247-291

Shoaib M, Stolerman IP, Kumar RC 1994: Nicotine-induced place preferences following prior nicotine exposure in rats. Psychopharmacology (Berl) 113: 445-452

Strakowsky SM, Sax KW, Setters MJ, Keck JR PE 1996: Enhanced response to repeated d-amphetamine challenge: evidence for behavioral sensitization in humans. Biol Psychiat 40: 872-880

Vanderschuren LJ, De Vries TJ, Wardeh G, Hogenboom FA, Schoffelmeer AN 2001: A single exposure to morphine induces long-lasting behavioural and neurochemical sensitization in rats. Eur J Neurosci 14: 1533-1538 
Vezina P, Stewart J 1990: Amphetamine administered to the ventral tegmental area but not to the nucleusaccumbens sensitizes rats to systemic morphine-lack of conditioned effects. Brain Res 516: 99-106

Vinklerova J, Novakova J, Sulcova A 2002: Inhibition of methamphetamine self-administration in rats by cannabinoid receptor antagonist AM 251. J Psychopharmacol 16: 139-143

Von Bohlen und Halbach O, Dermietzel R 2002: Neurotransmitters and Neuromodulators. Handbook of Receptors and Biological Effects, Wiley-VCH Verlag GmbH, Weinheim

Votava M, Krsiak M, Moravec V 2002: Effects of alprazolam and fluoxetine on morphine sensitization in mice. Physiol Res 51: 417-423

Wise RA, Bozarth MA 1987: A psychomotor stimulant theory of addiction. Psychological Rev 94: 469-492

Worsley JN, Moszczynska A, Falardeau P, Kalasinsky KS, Schmunk G, Guttman M, Furukawa Y, Ang L, Adams V, Reiber G, Antony RA, Wickham D, Kish SJ 2000: Dopamine D1 receptor protein is elevated in nucleus accumbens of human, chronic methamphetamine users. Molec Psychiatry 5: 664-672 